Olga Voronina

Herzen University

St. Petersburg, Russia

ovoronin@bard.edu

\title{
“THEY ARE ALL TOO FOREIGN AND UNFAMILIAR...": NABOKOV'S JOURNEY TO THE AMERICAN READER
}

\section{Recommended Citation:}

Voronina, Olga. “«They Are All Too Foreign and Unfamiliar...»: Nabokov's Journey to the American Reader". Metacritic Journal for Comparative Studies and Theory 3.2 (2017): https://doi.org/10.24193/mjcst.2017.4.02

\begin{abstract}
Both in Speak, Memory and in Strong Opinions, Nabokov insists on his early proficiency in English, French. This authorial stance makes it easy to believe that the writer's transition to English was easy. And yet, Nabokov's correspondence with publishers and his literary agent, Altagracia de Jannelli, reveals that this conversion was torturous and required extensive support from native speaker editors and translators. The essay documents Nabokov's inner turmoil at the time when he began to explore the British and American markets. In spite of the publication of Camera Obscura in England (1936) and, as Laughter in the Dark, in the US (1938), his other works' journeys to the Anglophone reader required time and effort. A close reading of the famous afterword to Lolita, a comparative analysis of Winifred Roy's translation of Camera Obscura and Nabokov's self-translation of Laughter in the Dark, and the perusal of the author's correspondence illustrate the difficulties he had to overcome in order to convey stylistic intricacy of his fiction to this new audience.
\end{abstract}

Keywords: Nabokov, Lolita, translation, self-translation, Camera Obscura

\section{Lolita and the Loss of Language}

Nabokov's English-language proficiency and the stylistic richness and variety of his prose are distinctive features of his authorship. The majority of studies of Nabokov's 
"American" oeuvre are predicated on the scholars' acceptance of the dazzling dexterity of his verbal gesture. Michael Wood calls the style of Nabokov's English "intricate and haunting and powerful" (Wood 23), while Brian Boyd describes his artistic genius as an ability to fuse "truth to detail with perfection of form, the exact with the evocative, an acute awareness of time with intimations of timelessness" (Boyd, Selected Essays 277). Even when critics note the "maddeningly opaque" language of Nabokov's fiction, chiding the rhythms of his prose for going "against the natural grain of English and American speech," as George Steiner did (Steiner 8), they cannot help paying tribute to the "charged, unstable mode of vitality" characteristic of his English words and phrases (Steiner 10, discussed in Trubikhina 11-14). Apart from Edmund Wilson's early attacks on Nabokov's idiom as insufficiently instinctive (e.g. Nabokov, Dear Bunny 56), his emergence on the American literary scene has been frequently presented - first and foremost, by the master himself, - as a graceful transition, a feat that a man claiming of growing up as a "perfectly normal trilingual child in a family with a large library" performed with an ease of a near-native speaker (Nabokov, Strong Opinions 43) ${ }^{1}$.

It is only recently that voices contradicting this vision have been raised. Boyd, for example, alludes to Nabokov himself when calling the language of The Real Life of Sebastian Knight "a second-rate brand of English" (Boyd, The Russian Years 496) while Neil Cornwell calls this novel "an apprentice work of the highest order" - but an apprentice work nonetheless (Cornwell 161). Robert Roper is, perhaps, most direct on this subject: he documents Nabokov's "feeling unreal in English" and suggests that in the early 1940s, even his irony "betrays unease, an awareness that the ground was shifting beneath his feet" (Roper 84, 86). Roper clinches this statement with a citation from Nabokov's letter to Wilson: "I envy so bitterly your intimacy with English words" (Roper 84).

I am going to further challenge the notion of carefree grace with which Nabokov switched from Russian to English by analyzing some of the steps he had to take in order to succeed as an American writer and translator. Specifically, I will add several confirming touches to other scholars' suggestions that, in the 1930-40s, Nabokov's

\footnotetext{
${ }^{1}$ In his autobiography, Nabokov repeatedly stresses his proficiency in other languages, asserting, for example, that he had "thoroughly and early mastered English and French" (Nabokov, Drugie berega 7; translated in Beaujour, Alien Tongues 95; see also Nabokov, Speak Memory 80, 113).
} 
English was far from supreme, causing him difficulties with publication of his works in Great Britain and the United States before and shortly after his arrival in the New World. Having no reason - and no desire, for that matter, - to belittle Nabokov's verbal virtuosity or doubt that the brilliance of his writing on the other side of the Atlantic sprouted from his life-long "affair" with the English language, I intend, instead, to underline this writer's tenacity in making English his own and turning himself into its indisputable prodigy years after his trilingual childhood, with all its spontaneity and intuitive linguistic competence, was over.

Like no one else, Nabokov was aware of the strenuous linguistic makeover that precipitated his becoming an American writer. But although his letters betray his insecurity and detail fear of failure ("(M)eanwhile, my separation from the Russian language dismays and torments me, and there's nightly heartburn from the Anglo-Saxon lentil soup," - to Aldanov, in 1941 [Bakhmeteff Archive]; "The book is progressing slowly because I get more and more dissatisfied with my English," - to Wilson again, in 1942 [Nabokov, Dear Bunny 75]), his public pronouncements of this kind are rare. One of such statements is the frequently cited concluding passage of Nabokov's essay "On a Book Entitled Lolita," dedicated to the juxtaposition of his "untrammeled, rich, and infinitely docile Russian tongue" and his self-acknowledged substandard English. The latter, he claims, is:

devoid of any of those apparatuses - the baffling mirror, the black velvet backdrop, the implied associations and traditions - which the native illusionist, frac-tails flying, can magically use to transcend the heritage in his own way (Nabokov, On a Book 76).

First made in 1956, sixteen years after the Champlain delivered the writer and his family to the New York harbor, this confession is supposed to recapitulate Nabokov's dissatisfaction with his capacity to control his adopted language. Strikingly explicit, it undermines the novel's literary elegance as well as its author's poetic signature - the exhilarating quality of writing that Martin Amis has compared to "a recreational drug more powerful than any yet discovered or devised" (Amis 1) - and poses a challenge to the enchanted readers who have just imbibed Lolita. The more attentive of them are forced to find out whether this is an act of exaggerated modesty or whether Nabokov is trying to hypnotize them into believing that his mastery in Russian - inaccessible to 
monoglot English speakers - is greater than the overwhelming radiance of this, his most celebrated, novel. The task is made even more difficult by the fact that "On a Book Entitled Lolita" itself neither explains what "untrammeled" and "rich" mean for Nabokov in his defining artistic proficiency in a language, nor clarifies why and how the writer's Russian "heritage" should become "transcended". It is a "mirror" of a confession, rather than a confession itself, and as such, it appears to be "baffling", indeed.

As any other Nabokovian mirror, though, it can be polished to clarity and then looked into again. The underlying metaphor here is that of an "illusionist" who "magically" outruns his own linguistic past to achieve a semblance of verity and effortlessness in the present. Juxtaposed with Nabokov's other evocations of reflections and refractions, the figure of the mirror draws readers' attention to the approach Nabokov wants them to use when interpreting his fiction as a work of narrative magic, championed in his Lectures on Literature - those reading guidelines pointing out to students that a great author is first and foremost an enchanter, a magician (Nabokov, Lectures 2, 6). Apart from that, the "On a Book Entitled Lolita" intimates a secret path to their reading Nabokov's Anglophone prose and poetry as a particular kind of literary work - the one that mesmerizes, transforms, and transcends. Finally, it is a looking glass that reflects not what the readers can see, but what the writer wants them to notice, specifically, a link that may exist between Nabokov's fiction writing and his work of translation. Although at least one critic has tried to downplay the influence Nabokov's self-translations have had on his evolution as a writer (Beaujour, Translation 719), these two creative pursuits nourished and sustained his artistry in English exactly because they were both exercises in the magical rendering of reality - and of language. After all, the "apparatuses" of an artful native-speaker storyteller as Nabokov sees them (the "mirror, the velvet backdrop") are the same tools a translator uses to transform the words of others with care and precision, but also with a great deal of artifice and deception.

Mirror-like illusion, therefore, is a concept that brings the three aspects of Nabokov's creative personality into focus: his perception of an acquired language's approximation of the native vernacular; his view of translation; and his artistic credo, the insistence on the writers' right to send fictional worlds spinning while holding their 
audience captive inside (Nabokov, Lectures 2). Even for Nabokov, though, illusionist's contrivances could be treacherous and not always easy to control. For example, whereas Walter Benjamin insisted on translation's ability to render the literary work's "essential substance - [...] the unfathomable, the mysterious, the poetic" (Benjamin 253), Nabokov, from the 1940 s on, considered this power redundant, if not outright destructive, and spurned the result of such an endeavor as a meaningless illusion. He proceeded to rid himself of it ruthlessly in the Onegin translation, which, in his own words, was "shorn of its previous verbal existence" (Nabokov, Problems of Translation 135), and other such projects, termed "laborious literal reproduction(s)" (Nabokov, On Adaptation 354). His switching to English and thus depriving himself of the language that was so versatile, wieldy, and miraculously obedient to his command, on the contrary, led to his predilection for simulacra - the mirror realities constructed to reflect and multiply ad infinitum what was absent or would forever remain distant, nonexistent, or outlawed.

No wonder Wood tells us that this magician is always in doubt. He prefaces his study of Nabokov's "performances, both in life and in art," with a comparison between the author's transition from Russian and English and a more abstract, almost metaphysical, sense of personal injury, the "loss which is neither denied nor accepted but painfully courted and dutifully embraced, as if it were death itself and also the only gate to a second life; loss reconstructed as discovery" (Wood 2). Perhaps this is why Nabokov - often seen as arrogant and definitely not willing to suffer critics gladly downplayed the value of his great literary undertakings, such as Lolita or the colossal Onegin endeavor, in the passages that concerned his use of other languages. Thus in "On Translating Eugene Onegin," a poem printed in The New Yorker in 1955, almost a decade before his solo translation and commentary finally appeared in print, he chose tropes of illusion and reflection to communicate the daunting task of conveying the richness and subtlety of Pushkin's masterpiece to the English-speaking audience:

Reflected words can only shiver

Like elongated lights that twist

In the black mirror of a river

Between the city and the mist (Nabokov, On Translating 34). 
This poetic statement on the fluid, ambiguous, and never fully precise nature of translation is just as deeply steeped in the idea of translator's inability to approximate the original as "On a Book Entitled Lolita" is steeped in the grief for the magician's lost toolkit. When Nabokov claims in the latter that the novel's English language is an imperfect reproduction of the author's other ideal tongue, he asserts that Onegin he translated and Lolita he authored with such passion, ingenuity, and tenderness belong to the same category of "reflected words": they are his, but not entirely, fully present, but with another narrative and linguistic life possible elsewhere, in a different era, in a time now gone or evolving on a parallel plane, like that of the Soviet Despotate where they speak a different brand of Russian. In other words, not only Nabokov turns Benjamin's conviction in the possibility of translating the "poetic" into an ellipsis of uncertainty, but he also paradoxically claims that Lolita exhibits the ultimate untranslatability of a work already removed from its author's native vernacular. Akin to his other post-1940s creations, it is afflicted with an innate disorder - the lack of correspondence to the Platonic ideal of a novel that could have been written in a Nabokovian Russian and yet was not.

Like many other tongue-in-cheek pronouncements Nabokov made, "On a Book Entitled Lolita" sounds bold no matter what angle you look at it. Does it really declare the imperfection of his acquired tongue? A beginning author who needs to prove his worth to publishers in Britain and the United States wouldn't admit just so much (Nabokov didn't). Neither would a translator, eager to receive his first commission. But Lolita's linguistic faultlessness and stylistic excellence - and, eventually, its overwhelming success, - made this statement, for the man who delivered it, both possible and desirable. Apart from establishing the novel's exceptionality, it staked Nabokov's claim on his adopted language, sounding as an admission only this writer could make, for he was yet the only one able to register the range of artistic deviations between his English and his Russian. Moreover, what a fantastic marketing device: if Nabokov's other language is more magical, his earlier works should be even more alluring than Lolita. "I have dazzled you in English," Nabokov seems to be saying to his publishers and readers. "Now acquire, translate, read my earlier Russian novels." (As we will see shortly, they did take notice, but not right away.) 
Whereas Lolita is a turning point in its author's writing career, bringing him financial success and global recognition that ranged from admiration to notoriety, Nabokov's essay on it is a rumination on the moment's import. Finally, Nabokov can publicly complain about the insufficiency of his English and disparagingly compare it to his Russian because he knows he had been wielding this "new" language with confidence for more than a decade and with amazing consequences. There's his success with translation: the poems by Pushkin, Lermontov and Tyutchev he rendered into English have merited a publication of Three Russian Poets (1945); the Onegin project is well under way; and the first draft of The Song of Igor's Campaign is already completed (its unpublished copies immediately made available to students at Harvard, Columbia, and Cornell)... (Goldblatt 661). And there is his prose: apart from Lolita (1955), he has published four other original works in English (The Real Life of Sebastian Knight (1941); Nikolai Gogol (1944); Bend Sinister (1947); and Conclusive Evidence (1951)); and is now finishing Pnin, which The New Yorker devotedly serializes. This same magazine almost unfailingly accepts his other chapters, poems and stories, having offered him an "option" - an exclusive right to receive all his publishable work first. No one needs to remember how strenuous his passage towards this mastery - and this confidence - has been. Nabokov cannot forget it, though. If, in 1941, he sends his wife a letter containing a rhetorical question the answer to which he knows too well ("Or shall I write one LITTLE PIECE IN RUSSIAN - and then translate it" [Nabokov, Letters to Véra 444]), his next year's confession to the same addressee sounds much rawer:

[A]a lightning bolt of undefined inspiration ran right through me - a passionate desire to write - and to write in Russian. And yet I can't. I don't think anyone who has never experienced this feeling can really understand its torment, its tragedy. In this sense, the English language is an illusion and an ersatz. In my usual condition, i.e. busy with butterflies, translations, or academic writing, I myself don't fully register the whole grief and bitterness of my situation (Nabokov, Letters to Véra 481-482).

In 1954 there ensues an even more anguished summary of the same situation. It's a year before Lolita appears in print; Nabokov has just completed translating Conclusive Evidence into Russian. In lieu of an apology to Katharine White, his editor at the New Yorker, for a 5-month-long delay with the submission of Pnin chapters, Nabokov recalls 
the "agony" he had to go through in the early 1940 s in order to switch from his native language to English. "I swore I would never go back from my wizened Hyde form to my ample Jekyll one," he muses, "but there I was, after fifteen years of absence, wallowing in the bitter luxury of my Russian verbal might" (Nabokov, Selected Letters 149). Then he proceeds to call the transition an "atrocious metamorphosis".

\section{"Doing my Little Boborokyn Act"}

When Nabokov began to reach out to British and American publishers, he had a body of work already heralded by the Russian emigration's leading critics as the diaspora's most powerful literary outcome. In 1932, Aldanov, who was older and had lived in Paris longer, showed him a bookshelf full of translations of his works into fourteen foreign languages - and that image lingered (Nabokov, Letters to Véra 193). Less than ten years later, it would be Aldanov to whom Nabokov reported on his success with English:

My English novel Sebastian Knight [...] will come out soon, and I have just received an "excited" response from Edmund Wilson whom publishers sent the proofs. I am proud of this book as my tour de force and a pure willpower phenomenon. Besides, an anthology of my translations is also coming out from the same New Directions, and a story and a poem, in the Atlantic, - I have spawned poetically in English for the first time [vpervye ostishilsya po-angliyski]! Also, I have translated and written commentaries to several poems by Khodasevich for a magazine. I am simultaneously writing a work on mimicry (with the refutation of "natural selection" and "struggle for life") and a new novel in English. In a word, je fais mon petit Boborykin (do you remember how he slammed himself on the thigh when talking to Turgenev [?]) (October 20 $0^{\text {th }}$ 1941, Bakhmeteff Archive).

Two curious facts surface in connection to this letter. First of them pertains to the ambivalence of Nabokov's feelings, for this passage precedes the statement cited earlier, in which Nabokov complains to Aldanov of the "heartburn" inflicted on him by the "Anglo-Saxon lentil soup" - his need to express himself in English. The second is the Boborykin reference. It leads to Niké, a grotesquely pompous character in Petr Boborykin's novella “He's Gotten Smarter" [Poumnel] (1890, in Boborykin 1993). Niké 
does tap his thigh in self-approval after pronouncing two particularly difficult French words in a company of ladies. Although Nabokov's self-satisfaction with his English exploits may well explain his alluding to this passage, his mentioning of Turgenev and the fact that Boborykin did not report on making such a gesture himself in his memoirs suggests the possibility of further inquiry. Perhaps Nabokov covered another writer with the Boborykin cloak? Apart from the juicy reminiscences about Turgenev by the author of "He's Gotten Smarter," there are also memoirs by another contemporary, Elisey Kolbasin, who had conversations with Turgenev, met him abroad and, most importantly, commented on the Russian novelist's perspective on addressing the American reading public. When Kolbasin visited with Turgenev in Karlsbad in 1873, he witnessed Turgenev's encounter with an entrepreneurial American admirer of his art. This ardent young man tried to convince the aging writer that he should come to the United States to read from his works. Fathers and Sons was very popular there because of its portrayal of nihilism, the American insisted, and if Turgenev agreed to enchant his audience the way Dickens had done it earlier (to the point of dancing onstage when the viewers requested it!), he would not only witness the audience's enthusiasm and earn eighty thousand dollars for his pains, but could also be assured of the foundation and subsequent prosperity of a large town named "Bazarov"; Turgenev commented on this proposal to Kolbasin with bitterness:

I am a humble Russian nobleman and would not dance silly even for the right to own both hemispheres of our planet. Just think of it, this American manipulator lied aplenty: his report on the fantastic Bazarov city is a pure fairy tale, and then, do notice that he is ready to have me read to the American public in Russian! (Kolbasin 26)

Proud as he was of his achievements on the American literary stage, Nabokov could not help being sympathetic to a response like Turgenev's. For him, switching to English was part of the very "struggle for life" he tried to refute in his lepidopterological writings. "Doing [his] little Boborykin act" meant performing in the language he knew well, but was not fully confident in as an artist. This is why the boastful passage in his letter to Aldanov ends in mild self-depreciation and leaves a bitter aftertaste. He could do it, but at what cost? And would he ever fully succeed? 
Nabokov always tackled his tasks brazenly. With his polyglot upbringing and excellent education, in the beginning of his literary career he did not consider either English or French a challenge - at least, not when he was converting texts from these languages into Russian. When contested by his father, he translated Colas Breugnon by Romain Roland from French, writing his parents from Cambridge: "Well, my darlings, I must finish now - I have absolutely no spare time: if I don't translate four pages a day, I feel such a scoundrel by the evening" (January 25 $5^{\text {th }}$ 1921, Bakhmeteff Archive). As a successful writer, he was not proud of Anya $v$ strane chudes, his 1923 translation of Carroll's Alice in Wonderland (Nabokov, Letters to Véra 184), but the work definitely left a trace, allowing Simon Karlinsky to call it "warm and witty" as well as "the standard Alice in Russian" (Karlinsky 310-315). Later, hardship occasioned Nabokov's attempts at translating from Russian into the languages he learned in his youth. In the lean decades in Berlin and Paris, he would translate into English newspaper editorials penned by an acquaintance, or a scientific paper on the anatomy and physiology of mice (Nabokov, Letters to Véra 36,434 ). Translations of his own stories into French began in 1932, and although mostly there were others involved - Doussia Ergaz, Denis Roche ("an ideal translator," according to the author [Nabokov, Letters to Véra 201]), a literary agency run by his Russian acquaintances, Nabokov's own creations in the language were already coming out in French journals, leading to a realization that he could manage just as well - and probably better. When Candide expressed interest in his "Russian" work, Nabokov tried to convince Véra that he could do it without others' help:

[...] I have to have the translations. Denis Roche, in principle, has promised me to translate, but he is too busy at work now. Mme Ergaz has been sick all this time. I will be at her place on Monday and offer her Music to translate. I have begun to translate Terra myself (Nabokov, Letters to Véra 210).

His self-translations to French did not work entirely as he hoped, though, definitely not gaining him the same acclaim as "Mademoiselle O," published on April $15^{\text {th }} 1936$, in Mesures, or the essay "Pouchkine, ou le vrai et le vraisemblable" ("Pushkin, or the Real and the Plausible"), which appeared in March 1937, in $L a$ Nouvelle Revue Française. In spite of Nabokov's optimism ("Yesterday I began to translate my Music for Candide - and it's turning out very well, very engagingly; I'll 
finish and submit tomorrow"; "You can congratulate me: last night I finished the French translation of Music (it has turned out, in my opinion, better than anything I've written in French)"; "Tomorrow I will be dictating to Raisa, for Candide, Musique [...]. If they take it, I'll interrupt writing the play for a three-day translation into French of yet another story - it's turning out much easier and more fun than I thought" [Nabokov, Letters to Véra $315,318,319]$ ), neither "Music" nor "Terra Incognita" seem to have appeared in French journals. The sign of things to come should have been the conversation with Jean Paulhan of La Nouvelle Revue Française who let Nabokov know that he found his translations of the Pushkin poems, to be included in "Pouchkine...," somewhat heavy and dull ("Paulhan is taking the conférence too, but he finds that the translations of the poems have no 'envolée' and, after consulting with him, I have sent them to Melo du Dy, for feathering" [Nabokov, Letters to Véra 285-6])2. In mid-to-late 1930s, publishers continued to push Nabokov manuscripts around, with only those meticulously translated by French native speakers making the final cut: Chambre Obscure (Camera Obscura), translated by Doussia Ergaz, came out from Grasset in 1934, followed by The Defence (La course du fou) from Fayard in 1934 and The Eye (L'aguet: nouvelle inédite) in the February, 1935, issue of Euvres libres - both in Denis Roche's translation3. In 1939, the French writer Jarl Priel translated Invitation to a Beheading and The Event (Nabokov's Course du fou, 1934).

When Nabokov began writing in and translating to English, he also had to solicit help from others. The British market was very attractive, and even American publishers began to ask him for fiction, but he hesitated to switch to the language he presumably knew better than French (Boyd, The Russian Years 432). Instead, Gleb Struve, a longtime close acquaintance, translated "Passenger" and "The Return of Chorb," while "Spring in Fialta" commissioned for Hundred Russian Short Stories was entrusted to

\footnotetext{
2 Melot du Dy, a Belgian poet and prose writer whose name tickled Nabokov, completed the task in less than two weeks, just in time for Nabokov's reading at Salle Chopin, as part of the Feux Croisés programme. Nabokov confirmed his contribution in his letter of February 12, 1937: "In the morning, the translations, rather prettily plumed by Melot, arrived, so I read some of them in two versions" (Nabokov, Letters to Véra 295).

3 "Spring in Fialta" also came out in Roche's translation (Nabokov 2015, 361). Nabokov was smitten by Roche's meticulous ways, writing to Véra: "He is now busy checking every phrase of his translation minutely, conscientiously and rather talentedly. He has already corrected many of the things you and I found there. [...] He (Roche) has got hold of a thick volume - chess and other games - and is drawing his information from there. To me, he's an ideal translator, in that sense" (Nabokov, Letters to Véra 201)
} 
the notorious Baroness Budberg (Berberova's "Iron Woman") - who failed to deliver (Nabokov, Letters to Véra 292, 318). Although in 1937 John Long did publish Nabokov's own translation of Despair to English (after producing, in 1936, Camera Obscura in Winifred Roy's translation), that venture almost got canned in its early stages. On June 11, 1936, Nabokov wrote to Véra: "My love, a letter from Long. Having excused himself for the 'delay', he carries on: 'up to the present, however, we have not made any plans for the publication of this book, the chief reason being that some of our Readers' reports have not been at all enthusiastic, especially in regard to your translation. In view of the latter, we are now writing to ask you whether it would be possible for you to get hold of the translation that the American publishers used?' What shall I answer?" (Nabokov, Letters to Véra 272). The situation was dire, because the translation circulated among American publishers was either the one in question or the Grasset's French version prepared by Ergaz.

To get Despair published in England, Nabokov asked Long to find him a copyeditor. That request did not fare well with the publisher who was afraid of extra costs and an indefinitely extended deadline. In his response Nabokov cited a "misunderstanding":

When suggesting that someone with a good English style should revisit my translation [,] I did not mean that he would have much work to do. I only wanted to be on the safe side. [...] I hope that the translation when I submit it to you will be fairly ready for publication (July $21^{\text {st }} 1935$, Berg Collection).

On December $8^{\text {th }} 1936$, Long's manager, H. J. Bourne, recommended the assistance of David Garnett, son of the prolific Russian-to-English translator Constance Garnett. Nabokov, who later would pour scorn on Garnett's translations, calling them "dry and flat, and always unbearably demure" (Nabokov, Nikolai Gogol 38), replied with enthusiasm: "[I]it was a great relief to read your letter [...] you seem determined to give my book a special treatment" (December $12^{\text {th }} 1936$, Berg Collection). But Garnett Jr. could not get involved, and Nabokov again solicited Struve's help. His letter contains a "serious and urgent" plea for an "Englishman with a good literary style who could have thoroughly edited [proredaktirovat'] [his] translation" ([undated]; Library of Congress). Instead of a man, however, Struve sent him a female: his twenty-five-year old student 
Molly Carpenter-Lee. She went over the text multiple times, made many corrections, and received a small remuneration for her services (Nabokov, Letters to Véra 307). It is likely that Carpenter-Lee also copy-edited Nabokov's translation of Camera Obscura issued under the title Laughter in the Dark by Bobbs-Merrill, an Indianapolis firm, in 1938.

Yet another effort, by outsiders, to render Nabokov's texts into English and French took place under the aegis of Mark Lvovich Slonim's European Literary Bureau. Nabokov first went to see Slonim (who was not directly related to Véra), on November 22, 1932. He gave him "a three-month option for the English $\mathrm{K}<\mathrm{ing}>\mathrm{Q}<\mathrm{ueen}>$, K<nave >," which, in the author's words, "they wanted badly" (Nabokov, Letters to Véra 229). The collaboration with Slonim continued throughout the 1930s. There is an original of Slonim's letter to Nabokov at the Library of Congress, dated March $7^{\text {th }} 1935$. It lists seven projects related to placing translations of Nabokov's works with French, Italian, Hungarian, Norwegian, Danish, and Polish publishers. Slonim asked Nabokov insistently for translations into English - "they are in high demand in Scandinavian countries" (March $7^{\text {th }} 1935$, Library of Congress). The agent himself translated several stories ("The Return of Chorb," "Pilgram") into French with the help of his ex-wife, Susanne Campaux. Nabokov was pleased with the result, but, typically of him, with restrictions: "The translation, overall, is beautiful," he wrote to Véra, "but there are lots of imprecisions, although they did try very hard" (Nabokov, Letters to Véra 257).

Nabokov's first attempts at writing in English also required native speakers' intervention. In 1937, he gave the first version of his autobiography, "It Is Me," to Carpenter-Lee, writing to Véra on the occasion of her returning the manuscript: "Molly has given me an excellently corrected 'autob[iography]' and now I'm hurriedly transferring her corrections to my copy, so as not to be left without anything" (Nabokov, Letters to Véra 303). In 1939, he solicited the help of Lucie Léon Noel, the sister of Alexander Ponizovsky, his friend at Cambridge and the wife of Paul Léon, lawyer, historian of literature, and James Joyce's secretary, in copy-editing The Real Life of Sebastian Knight, which was written in haste to be submitted to a literary competition in England. Nabokov's anxiety "that this first novel in English should sound neither 'foreign' nor read as though it had been translated into English," led to weeks of heavy collaboration, several afternoons a week, with the two of them reading the manuscript 
out loud, replacing words, deleting wrong idioms and paraphrasing whole passages (Boyd, The Russian Years 503; Nabokov, Letters to Véra 638; Cornwell 158; Noel 210)4.

Writing in English (and, for that matter, French) and getting his stories and novels published helped Nabokov gain self-assurance, which affected his perception of how his work was translated by others and carried over into his own attempts to translate without help. The letter he sent in 1935 to Hutchinson, the parent company of John Long, Ltd., regarding Winifred Roy's translation of Camera Obscura, is much more cocky and offensive than the rejections he would soon receive himself from them and other Anglophone publishers. Nabokov criticized Roy's work for its being "loose, shapeless, sloppy, full of blunders and gaps, lacking vigor and spring, and plumped down in such flat, dull English that I could not read it to the end" (Nabokov, Selected Letters 13). In a similar vein, shortly before asking Carpenter-Lee or Léon to assist him (to be precise, on February 4, 1936), he sent his wife a note regarding his first translation of Despair, instructing her not to look further for any native speakers to copy-edit his work:

I beg you, send the translation to Long without delay (enclosing or not, as you wish, the little letter I enclose here). The things noted and corrected - all of that means absolutely nothing - any Russian reader can find just as many birthmarks on any page of any of my Russian novels, and as your Englishwoman remarked, any (good) English writer allows himself just the same grammatical inaccuracies. Please, don't upset British majors and old maids, but send to England the copy I prepared, without inserting a single one of the corrections others have made. [...] Please send it right away (Nabokov, Letters to Véra 245-246).

Long's disapproval of this self-translation, cited in the letter to Véra of June $11^{\text {th }}$ 1936, again made Nabokov fluctuate between uncertainty and confidence in his mastery

\footnotetext{
4 Lucie Léon Noel reminisced on her editorial help to Nabokov in "Playback," TriQuarterly 17 (Winter 1970), 209 - 219. In a rare response to commemorative, biographical, and critical notes published in that festschrift issue, Nabokov added even more detail to her recollections: "The extent to which I was concerned with the fragility of my English at the time of my abandoning Russian in 1939 may be gauged by the fact that even after Mrs. Léon had gone over the manuscript of my Sebastian Knight in Paris where it was written, and I had moved to the USA, I begged the late Agnes Perkins, the admirable Head of the English Department at Wellesley, to assist me in reading the galleys of the book [...], and that later, another kind lady, Sylvia Berkman, checked the grammar of my first English stories that appeared in The Atlantic in the early forties." (Nabokov, Strong Opinions 292).
} 
of English. For example, he sounded both hesitant and self-assured five months later, when writing to his publisher ("I was, I confess, just a little surprised by your letter [...] However, after careful consideration I began to think that, perhaps, your readers' perplexity was not so much caused by an imperfect translation - though I am by no means against your having it slightly revised - as by the peculiar character of the work itself and by a certain singularity of style which was part of the author's deliberate intention" [June 29 $9^{\text {th }} 1936$, Berg Collection]). But in Nabokov's response to his American literary agent Altagracia de Jannelli sent on November $16^{\text {th }}$, the translator's insecurity was replaced with the author's repudiation of translation as an imperfect, even destructive vehicle of conversion from one language into the other:

[...] my novels [...] belong to Russia and her literature, and not only style but subject undergoes horrible bleeding and distortion when translated into another tongue. The German version of 'King, Queen, Jack' < King, Queen, Knave> is a cheap travesty; 'Camera Obscura,' which, in Russian, was meant as an elaborate parody, lies limp and lifeless in John Long's and Grasset's torture-houses, and 'Despair' which is something more than an essay on the psychology of crime, turns out to be a half-baked thriller - even when I translate it myself. Strange indeed are the 'fata' of my books! (November 16, 1936, Berg Collection)5.

Later, Nabokov would make sure that it was he and no one else who controlled the "fata" of his Russian books in English, French, and a number of other European languages. According to Christine Raguet-Bouvard, it was Nabokov's negotiations with Long (in particular, his intent to oust Roy by producing a new version of Camera, retitled Laughter in the Dark) that led to his eventual decision not simply to translate his novels himself, but to partially rewrite them. It would be nearly impossible for him to find a translator "blessed with as much talent as the author so as to be able to create a text of equivalent quality in translation," Raguet-Bouvard suggested (1995). In the 193040s, however, still in the throes of "metamorphing" into an Anglophone writer, Nabokov was looking for the ways to make his English work for him on many levels - be it in translation, self-translation, or creating original works. His reference to editorial

5 This letter is misdated in Nabokov, Selected Letters as "November $16^{\text {th }} 1938$ ?" 
"torture-houses" was, most likely, not just an apt metaphor, but also a commentary on the state of his mind.

\section{The Metamorphosis}

De Jannelli knew better than most people what this author meant when complaining about the peculiar fate of his books in translation. Regularly forwarding him rejection slips from American publishing houses, she was aware that many of them commented on the foreignness of Nabokov's prose and the questionable quality of his and others' translations into English. Thus, on July $10^{\text {th }} 1935$, Henry Holt and Company responded: "We have examined LUZHIN'S DEFENSE by V. Sirin and regret that we do not find it adapted to our list" (Library of Congress). On July $9^{\text {th }} 1938$, there came a response from Bobbs-Merrill: "[...] each one of Nabokoff's books presents its individual difficulty as well as the one common to all - that they are all too essentially foreign and unfamiliar to carry an American audience" (Library of Congress). Charles Scribner's Sons responded on July $27^{\text {th }}$ of the same year: “Despair' is [...] the best suited to publication in American, and yet even here, we cannot foresee more than a limited sale. It is a strange book and suffers to some extent [...] from this peculiar method of the author [...]" (Library of Congress). In August 1939, Bobbs-Merrill again returned a Nabokov manuscript, this time with the verdict: "[...] the exact form of the book never fully emerges and [...] it is often, for this reason, needlessly difficult to follow. It would require a great deal of detailed editorial work" (Library of Congress) ${ }^{6}$.

It is not surprising, then, that the question of translation, self-translation, and writing in English often arose in Nabokov's correspondence with de Jannelli, who, at a certain point, reported to her author the words of James Cameron of Bobbs-Merrill: "I am afraid nobody but Nabokoff can translate Nabokoff" (De Janelli to Nabokov, May $8^{\text {th }}$ 1938, Berg Collection). When the literary agent kept asking for more work in English, Nabokov tried to comply, writing, in June of 1937: "Ready to postpone everything for

\footnotetext{
${ }^{6}$ It must be noted that de Jannelli introduced Nabokov to Peter Pertzov, his earliest and best American translator. Fortunately for everyone involved, the translation of "Cloud, Castle, Lake" Pertzov produced in collaboration with the author enraptured Edward Weeks, the editor of The Atlantic Monthly, who responded to the submission enthusiastically. As Nabokov reported to Véra, Weeks said: "We are enchanted with your story, it is just what we have been looking for, we want to print it at once, and much more sweet talk. He asked for more and more" (Nabokov, Letters to Véra 443). For a detailed analysis of Nabokov's work with Perzoff, see Shrayer 157-165.
} 
the American case. If I start translating soon, I can prepare at least one more book [in English] for the fall" (On the back of De Janelli to Nabokov, June $26^{\text {th }}-28^{\text {th }} 1937$, Berg Collection). But he could not keep up with the pace of her requests and submissions, eventually suggesting that she gave up offering American clients all the books except Camera Obscura and Despair, already under contract with British publishing firms (Nabokov, Selected Letters 14). Neither could he accept de Jannelli's constant nagging similar in tone to publisher's reader reports and rejections - about the "foreign and unfamiliar" quality of his work in English. From month to month, Nabokov's selfdefense grew stronger, along with his determination to invent a method which would help him win around this new audience:

Not only have I made the translation [of Camera Obscura], but the translation I made is very good indeed, and this is a matter in which I deem myself a sound judge. I may be not much good as a businessman, but this characteristic has nothing whatever to do with the literary task which was set me and which I insist on having performed with the utmost care and very successfully. I got so puzzled by your letters that I looked again at my work, comparing it with the Long translation, and cannot imagine that the sentences which the two versions have in common can make them appear identical particularly as such as for instance 'Fräulein Peters? she repeated. I think she's moved from here. You'd better ask. Fifth floor, left-hand door,' etc (p. 70) or 'his knee hit against something, which wobbled and jingled - probably a child's bicycle' (p. 283) [.] I don't see how they can be improved, the more so as I myself made them as literal as possible (especially the part revising the Long translation. The only way would be to change the sense - which would lead to writing a new novel. The task of changing every word while retaining the whole sense would be rather like that competition I saw in a London paper to-day: express the meaning (of a given proverb) without using once the letter 'e.' It would be rather amusing to know at what degree of similarity does copyright trouble start on such occasions - you know the sophist's problem: at what number of remaining hairs does a head begin to be called bald (January 31, 1938, Berg Collection).

This long citation from a largely belligerent letter exposes Nabokov's strategy of domesticating his prose in America. On one hand, it demonstrates the writer's commitment to translate "with utmost care" - the intent that would eventually become a paradigmatic feature of the Onegin translation. On the other, it makes obvious his 
preference for rewriting, rather than translating, his "Russian" works in English. It's not that the idiom is unwieldly or that his skill is wanting, Nabokov says. Rather, his fiction has a language of its own, and it cannot be taken apart, word by word, like a proverb in a newspaper puzzle. To write in English, he needs to invent a whole new language, the Nabokov English idiom. And invent he did - from Laughter in the Dark, parsed by Jane Grayson as an example of "cross-fertilization between Nabokov's English and Russian writings" (Grayson 56), to Lolita and beyond - the whole vista of literary words that, according to Irwin Weil, "show a truly rare penetration into the American language by a foreign artistic perception" (Weil 272).

A scholar and a scientist, Nabokov was eager to compare this invention to his work on butterfly taxonomy, more specifically, to his work on Lycaeides, or "Silver studded Blues." Describing this "immense" labor in a letter to Wilson - dissecting hundreds of specimens, filling out index cards with "thousands of references," drawing and describing morphological features of his "leps" - he called it his "training in the use of our (if I may say so) wise, precise, plastic, beautiful English language" (Nabokov, Dear Bunny 126). His "taxonomic adventures," Nabokov said, "read like a novel” (Nabokov, Dear Bunny 126). They also involved taking things apart, but in this case, he was both appropriating and reinventing the language of science when crafting his masterwork the story both of artistic discovery and of scientific pursuit.

The letter to de Jannelli marked the moment of Nabokov's beginning to transform his creations for the audiences otherwise unable to perceive the richness and variety of his other vernacular. He had just completed Laughter in the Dark, which, with the likely help from a native speaker editor, would soon find an American publisher. As Nabokov's first attempt to "abridge, expand, or otherwise alter or cause to be altered, for the sake of belated improvement, one's own writing in translation" (Nabokov, Invitation 6-7), this work stands out among his self- and edited translations both chronologically and in essence. Unlike his own rendering of Despair to English7, which de Jannelli tried to offer American publishers for several years and never

\footnotetext{
7 See Nabokov, 1937. The author's unhappiness with his translation transpires in his comment on its being unavailable to post-war readers: "The only copy extant is, as far as I know, the one I own - but two or three may be lurking amidst abandoned reading matter on the dark shelves of seaside boarding houses from Bournemouth to Tweedmouth" (Nabokov, Despair xii). Apart from its being a name of a real town in Dorset, Bournemouth is also a reference to H. J. Bourne, the manager of John Long, Ltd., with whom Nabokov corresponded.
} 
managed to place ${ }^{8}$, and his Russian novels that would come out in the US after Lolita's success (Invitation to a Beheading, 1959; The Gift, 1963; The Defense, 1964; The Eye, 1965; Despair, 1966; King, Queen, Knave, 1968; Mary, 1970; and Glory, 1971), it was his own translation only edited by a native speaker, rather than another translator's work, his son's included, that Nabokov revised9. This is why Grayson believes that Laughter heralds Nabokov's “own 'translation' from European to American soil” (cited in Classe 988), while Raguet-Bouvart sees in it a sign of the irrevocable and beneficial transformation of his authorial self - the act which "enriches him as much as it does the text and is possible only because he has been able to enrich himself throughout the chain of successive interventions: the author [...] divided to become both author and reader, then author and reader and translator, and finally [...] reverted to his initial status of author to open up the horizon of a text which, in every language of translation, concludes with an open door" (Raguet-Bouvart 125).

The import of an "open door" as a symbol of linguistic border-crossing as well as of Nabokov's changing authorial identity becomes especially manifest in Laughter in the Dark as an "abridged, expanded," and "otherwise altered" version of Camera Obscura. According to Grayson's perceptive analysis, the motif of doors recurs both in Camera and in Laughter, but it is in in the latter that the author not only increases the emphatic mention of his protagonists' exits and entrances, but also chooses to include a metatextual comment on their import (Grayson 48). When Albinus struggles with the locked door to the bathroom which separates his bedroom from the room where Margot cavorts with Axel Rex, a voice of greater authority than that of the character reveals that he was "quite unconscious of the queer part doors played in his and her life" (Nabokov, Laughter in the Dark 205). At the end of the novel, where the narrative acquires its distinctly "cinematic" features (Appel 1974, Seifrid 1996, Mazierska 2010), the image of the door opens and closes the paragraph which contains the description of the room in which Margot has just killed Albinus. The room's disarray and barrenness encapsulates the chaos and moral emptiness of the protagonist's life, while Nabokov's mention of the

\footnotetext{
8 Nabokov's re-translation of this novel came out in the US only three decades later. In the introduction to this reworked version, Nabokov suggested that his young self should have been "pleased and excited" with the result. (Nabokov, Despair xii).

9 Olga Anokhina calls these collaborations a "multilingual and polymorphous genesis" and asserts that translators' style "feeds" the writing of Nabokov just as his writing affects their style (Anokhina 111-129).
} 
two open doors (one, to the hall, and another, "leading from the hall to the landing") not only points out Margot's escape, but also traces a symbolic trajectory of Albinus's soul departing from the "big, soft doll" of his body (Nabokov, Laughter in the Dark 292). Overall, this last paragraph perfectly captures the changes in Nabokov's re-crafting his narrative in English. Apart from the shift in the storytelling mode (from novelistic to cinematic), it now includes an important adjustment to the plot by means of the narrator's indication that the cabinet which previously contained the master's precious miniatures is now empty (Margot has stolen them). There is also an expansion of the death as drowning motif, which begins with the dying Albinus's interior monologue: "I must keep quiet [...] and then walk very slowly along that bright sand of pain, toward that blue, blue wave" ([1938, 291] Cf. in Russian: “[...] nuzhno posidet' minutku sovershenno smirgo, posidet', potom potikhon'ku poyti po pesku k siney volne, $\mathrm{k}$ siney, net, k sine-krasnoy v zolotistykh prozhilkakh volne" [Nabokov, Kamera obskura 240]). In Laughter, Nabokov adds a description of the crumpled carpet, "bulging up at table foot in a frozen wave" (Nabokov, Laughter in the Dark 292) and thus turns the still-life of a murder scene into a landscape of his character's demise.

If we compare this passage to Roy's translation, which, supposedly, followed the original rather closely, we will notice several major deviations from Nabokov's narrative mode both in Russian and in the 1938 self-translation. While Nabokov grounds the death of Albinus in the timeless moment of metaphysical border-crossing by narrating the final scene in both present tense and past tense in Russian and entirely in present in English (“[...] door - wide open. Table - thrust away from it.” [Ibid.]), Roy chooses to adhere to the past tense, in which previous scenes were also narrated: "The door to the hall was wide open. The table was thrust to one side" (Nabokov, Camera Obscura 288) ${ }^{10}$. Roy's other stylistic choices include her triple repetition of the verb "to lie" in the description of objects in the room, whereas Nabokov, in Russian, uses the verb "lezhat' [to lie]" only once, replacing it with a more expressive verb "valyat'sya [to sprawl]" and omitting the verb altogether in two other cases. In his 1938 reworking of the novel, he also uses verbs of position sparingly. Most importantly, he noticeably omits predicates altogether, leaving some sentences verbless: "Table - thrust away from it. [...] Cabinet

10 I am very grateful to John Hoffnagle for his letting me see this rare edition from his collection of Nabokoviana and for Terry Myers's generous help in this matter. 
where the miniatures had been - empty" (Nabokov, Laughter in the Dark 292). This choice reinforces the stillness of the scene and makes it even more grounded in the eternity of death and the "otherworld".

The horizon of the text, indeed, opens here, for even this small example shows that the difference between translation performed by an outsider and the reworking of the original in English by the author himself contains textual transformations on all four narrative levels crucial for Nabokov: plot (Margot's stealing the miniatures), genre (novelistic narrative morphing into a script), style (the recurrent motif of death as drowning), and metaphysics (open door as an invitation to the contemplation of the death narrative as grounded in timelessness). Thus, in Laughter in the Dark, Nabokov not only takes greater authorial control of his earlier work, as Grayson suggests (43), but he also reinforces his capacity for crafting works of fiction ontologically (as previously nonexistent and uninhabited worlds), poetically, and linguistically. The wave of death that swallows Albinus is the same swelling body of water that engulfed Ivanov in Nabokov's short story "Perfection" ("Sovershenstvo", 1932) and that would later devour and then give new life to Lucette the mermaid in Ada, or Ardor: A Family Chronicle (1969). What matters here is not as much the continuity of the motif as its powerful originality and relevance in the English text that asserts its right for existence outside of the author's Russian oeuvre. Nabokov's “metamorphosis” into an American writer might be "atrocious," but it was obviously not undergone at the expense of the reader. The author's pain, in this work as well as in many others, is our gain - a beautiful illusion of perfection that we long to believe in.

\section{An Afterword}

Nabokov's final transition to English, and especially to writing in the language without assistance happened not in Europe, but in America, where he had to teach, communicate as well as write in the language. In the early 1940 s, the diligent, respectful, and kindly attention of Katharine White and C. A. Pearce, his editors at The New Yorker, allowed him to polish his grammar and syntax and gain familiarity with the intricacies of the English idiom, thus avoiding previous reliance on others' perfecting his works. Nabokov's correspondence with The New Yorker, now archived at the New York Public library, documents editorial corrections of such slips of his pen as "the horny sex" 
as a newly-coined name for butterfly genitalia or White's making sure that all his pronouns had proper antecedents ("I am sure you will okay this change because it is not a matter here of diagramming or over-exactitude. It's simply that it's not good English. A telephone call isn't a 'she.' Also it puzzles the reader who thinks something has been left out by the printer" [June $7^{\text {th }} 1945$, Berg Collection]). Although, in vein with his response to de Jannelli, Nabokov continued to resist the line-editing of his submissions to the magazine, including Harold Ross's rude interference in his work, he welcomed White's and Pearce's coaching, thanking the latter profusely on the occasion of "horny sex": "I am most grateful to you for your saving that line from an ignorance-as-bliss disaster. And that nightmare pun [...] This has somewhat sobered me - I was getting rather pleased with my English" (Early 1943, Berg Collection).

Nabokov's correspondence with The New Yorker from the early to mid-1940s shows that his rapidly increasing facility in English was coupled not with a genius's marveling at his verbal and artistic powers, but with a sober attitude predicated on a strong desire to avoid linguistic disasters. It is this attitude that brings us back to "On a Book Entitled 'Lolita'," in which Nabokov bemoaned the loss of Russian and suggested that his English was not nearly as satisfactory. If anything, it may help to explain not why the statement was made, but for whom. I believe it was directed towards the reader who, in the wake of Lolita's notoriety, hastened to embrace Nabokov as a new kind of an American writer - a successful transplant, so to speak, a man who had crossed the threshold of the English language to make himself a new home in it. That reader was yet unaware of the battle with the acquired tongue, that well-appropriated and yet foreign vernacular, fought by Nabokov for decades in spite of his self-professed trilingualism. It was not the existence of his "untrammeled, rich, and infinitely docile Russian tongue" that Nabokov wanted to celebrate. It was the "tragedy" of his overcoming the resistance of the other medium, other tool, other language, that he revealed with such grace. As any tragedy - Sophoclean, Shakespearean, Nabokovian - it was supposed to captivate his audience - even, perhaps, to make it undergo a catharsis. 


\section{References:}

Amis, Martin. "Martin Amis on Lolita," The Nabokov Centennial, http://www.martinamisweb.com/commentary_files/on_lolita.pdf, published on April $17^{\text {th }}$. Accessed October $4^{\text {th }} 2017$.

Anokhina, Olga. "Vladimir Nabokov and His Translators: Collaboration or Translation under Duress?" In Collaborative Translation: From the Renaissance to the Digital Age. Edited by Anthony Cordingley and Céline Frigau Manning. London: Bloomsbury, 2016.

Appel, Alfred Jr. Nabokov's Dark Cinema. New York and Oxford: Oxford University Press, 1974.

Beaujour, Elizabeth Klosty. "Translation and Self-Translation." In The Garland Companion to Vladimir Nabokov. Edited by Vladimir Alexandrov. New York and London: Garland Publishing, 1995.

---. Alien Tongues: Bilingual Russian Writers of the "First" Emigration. Ithaca: Cornell University Press, 1989.

Benjamin, Walter Selected Writings, Volume 1: 1913-1926. Cambridge, Mass.: Harvard University Press, 1996.

Boborykin, Petr. "Poumnel”. In Boborykin P. D. Sochineniya $v 3 t$. Vol. 2. Moscow: Khudozhestevnnaya literatura. 1994. http://az.lib.ru/b/boborykin_p_d/text_0130.shtml Accessed October 4, 2017.

Boyd, Brian, and Stanislav Shvabrin, eds. Verses and Versions: Three Centuries of Russian Poetry. Translated by Vladimir Nabokov. Orlando: Harcourt, 2008.

Boyd, Brian. Stalking Nabokov: Selected Essays. New York, Columbia University Press. 2011.

---. Vladimir Nabokov: The Russian Years. Princeton: Princeton University Press, 1990. Brown, Clarence. "Krazy, Ignatz, and Vladimir: Nabokov and the Comic Strip." In Nabokov at Cornell. Edited by Gavriel Shapiro. Ithaca and London: Cornell University Press, 2003. 
METACRITIC JOURNAL FOR COMPARATIVE STUDIES AND THEORY 3.2

Classe, Olive, ed. Encyclopedia of Literary Translation into English: A-L. London: Fitzroy Dearborn Publishers, 2000.

Connolly, Julian W. "Laughter in the Dark." In The Garland Companion to Vladimir Nabokov. Edited by Vladimir Alexandrov. New York and London: Garland Publishing, 1995 .

Cornwell, Neil. "From Sirin to Nabokov: the Transition to English." In The Cambridge Companion to Nabokov. Edited by Julian Connolly. Cambridge: Cambridge University Press, 2005.

Goldblatt, Harvey. "The Song of Igor's Campaign." In The Garland Companion to Vladimir Nabokov. Edited by Vladimir Alexandrov. New York and London: Garland Publishing, 1995.

Grayson, Jane. Nabokov Translated: A Comparison of Nabokov's Russian and English Prose. Oxford and London: Oxford University Press, 1977.

Karlinsky, Simon. "Anya in Wonderland: Nabokov's Russified Lewis Carroll." In Nabokov: Criticism, Reminiscences, Translations, and Tributes. Edited by Alfred Appel, Jr. and C. Newman. Evanston: Northwestern University Press, 1970.

Kolbasin, Elisey. "Iz vospominaniy ob I. S. Turgeneve." In I. S. Turgenev $v$ vospominaniyakh souremennikov, Vol. 2. Moscow: Khudozhestvennaya literatura, 1983.

Léon Noel, Lucie. “Playback.” In TriQuarterly 17 (Winter 1970), 1970.

Mazierska, Eva. Nabokov's Cinematic Afterlife. Jefferson, North Carolina: McFarland \& Co., 2010.

Nabokov, Vladimir. Kamera obskura. Berlin: Parabola, 1933.

---. Course du fou [The Defense]. Translated by Jarl Priel. Paris: Librairie Arthème Fayard, 1934.

---. Camera Obscura. Translated by Winifred Roy. London: John Long, 1935.

---. Laughter in the Dark. Indianapolis: The Bobbs-Merrill Company, 1938.

---. Despair. London: John Long, 1937. 
---. Nikolai Gogol. New York: New Directions, 1944.

---.. Invitation to a Beheading. New York: G. P. Putnam’s Sons, 1959a=.

---. “On a Book Entitled Lolita.” Encounter 4: 73-76, 1959.

---. “On Translating Eugene Onegin.” New Yorker, January 81955.

---. Despair. New York: G. P. Putnam’s Sons, 1966.

---. Drugie berega. Ann Arbor, Mich.: Ardis, 1978.

---. Lectures on Literature. Edited by Fredson Bowers. San Diego, New York, and London: Harcourt, Inc., 1980.

---. Selected Letters, 1940-1977. New York: Houghton Mifflin, 1989.

---. Speak, Memory: An Autobiography Revisited. New York: Vintage, 1989.

---. Strong Opinions. New York: Vintage, 1989.

---. "Problems of Translation: Onegin in English." In Theories of Translation. Edited by Rainer Schulte and John Biguenet. Chicago: Chicago University Press, 1992.

---. Dear Bunny, Dear Volodya: The Nabokov-Wilson Letters. Berkeley: The University of California Press, 2001.

---. "On Adaptation." In Verses and Versions: Three Centuries of Russian Poetry. Edited by Brian Boyd and Stanislav Shvabrin. Orlando: Harcourt, 2008.

---. Letters to Véra. Edited by Olga Voronina and Brian Boyd. New York: Knopf, 2015.

Raguet-Bouvart, Christine. "Camera Obscura and Laughter in the Dark, or, The Confusion of Texts.” https://www.libraries.psu.edu/nabokov/ragko1.htm Originally published as "La lecture du texte traduit." Palimpsestes 9: 119-134. 1995. Translated by Jeff Edmunds on Zembla. Accessed October 4, 2017.

Roper, Robert. Nabokov in America: On the Road to Lolita. New York: Bloomsbury, 2015 .

Seifrid, Thomas. "Nabokov's Poetics of Vision, or What 'Anna Karenina' is Doing in 'Kamera obskura”. Nabokov Studies, 1996. 
Shrayer, Maxim D. "V.V. Nabokov i ego amerikanskiy perevodchik P. P. Pertsov [V.V. Nabokov and His American Translator P.P. Perzoff].” Tallinn 23: 157-165, 2001.

Steiner, George. Extraterritorial: Papers on Literature and the Language Evolution. New York: Atheneum, 1976.

Trubikhina, Julia. The Translator's Doubts: Vladimir Nabokov and the Ambiguity of Translation. Boston: Academic Studies Press, 2015.

Weil, Irwin. "Odyssey of a translator." In For Vladimir Nabokov on His Seventieth Birthday. Edited by Charles Newman and Alfred Appel, Jr. TriQuarterly 17 (Winter): 266-283, 1970.

Wood, Michael. The Magician's Doubts: Nabokov and the Risks of Fiction. Princeton: Princeton University Press, 1994.

\section{Archival holdings}

Bakhmeteff Archive, Rare Books and Manuscript Library, Columbia University:

Nabokov, Vladimir to Elena and Vladimir Nabokov. January 25, 1921.” In Nabokov Family Papers, 1882-1950. Box 1.

Nabokov, Vladimir to Mark Aldanov. October 20, 1941. In Mark Aleksandrovich Aldanov Papers, 1926 - 1957. Box 6.

\section{The Vladimir Nabokov Archive, Henry W. and Albert A. Berg Collection, The New York Public Library:}

De Jannelli, Altagracia to Vladimir Nabokov. May 8, 1938. In De Janelli, Altagracia, Typescript Letters to Vladimir Nabokov, June 26, 1937 - November 24, 1941. Folder 1.

De Jannelli, Altagracia to Vladimir Nabokov. June 26-28, 1937. In De Janelli, Altagracia, Typescript Letters to Vladimir Nabokov, June 26, 1937 - November 24, 1941. Folder 3.

Nabokov, Vladimir to Altagracia de Jannelli. November 16, 1936. In De Janelli, Altagracia, Typescript Letters to Vladimir Nabokov, June 26, 1937 - November 24, 1941. Folder 1. 
Nabokov, Vladimir to H. J. Bourne. December 12, 1936. In Vladimir Nabokov's Correspondence with John Long, Ltd., July 21, 1935 - February 12, 1947. Folder 1.

Nabokov, Vladimir to John Long, Ltd. July 21, 1935. In Vladimir Nabokov's Correspondence with John Long, Ltd., July 21, 1935 - February 12, 1947. Folder 1.

Nabokov, Vladimir to John Long, Ltd. June 29, 1936. In Vladimir Nabokov's Correspondence with John Long, Ltd., July 21, 1935 - February 12, 1947. Folder 1.

White, Katharine to Vladimir Nabokov. June 7, 1945. In Vladimir Nabokov, Correspondence with The New Yorker. Folder 5.

Nabokov, Vladimir to C. A. Pearce, early (?) 1943. In Vladimir Nabokov, Correspondence with The New Yorker. Folder 1.

\section{Vladimir Vladimirovich Nabokov Papers, Manuscript Division, Library of Congress:}

Henry Holt and Company to Altagracia de Jannelli. July 10, 1935. In Correspondence, 1923-1952. Microforms. Box 1, Reel 1.

Morrow, Elizabeth M., The Bobbs-Merrill Company, to Altagracia de Jannelli. July 9, 1938. In Correspondence, 1923-1952. Microforms. Box 1, Reel 1.

Morrow, Betty The Bobbs-Merrill Company, to Altagracia de Jannelli. August 28, 1939. In Correspondence, 1923-1952. Microforms. Box 1, Reel 1.

Nabokov, Vladimir to Gleb Struve. Undated. In Nabokov's Correspondence with Gleb Struve. Microforms. Box 22, Reel 13.

Slonim, Mark to Vladimir Nabokov. March 7, 1935. In Correspondence, 1923-1952. Microforms. Box 1, Reel 1.

Wheelock, John Hall, Charles Scribner's Sons, to Altagracia de Jannelli. July 27, 1938. In Correspondence, 1923-1952. Microforms. Box 1, Reel 1. 